\title{
Loan Loss Provisions, Earnings Smoothing and Capital Management Under IFRS: The Case of Deposit Money Banks in Nigeria
}

\author{
Clement Chiahemba Ajekwe ${ }^{1, ~ *, ~ A d z o r ~ I b i a m k e ~}{ }^{1}$, Marie Fagson Silas ${ }^{2}$ \\ ${ }^{1}$ Department of Accounting, Benue State University, Makurdi, Nigeria \\ ${ }^{2}$ Internal Audit Department, Nasarawa State University, Keffi, Nigeria \\ Email address: \\ cajekwe@bsum.edu.ng (C. C. Ajekwe),nickibiamke@yahoo.com (A. Ibiamke), riesilas@yahoo.com (M. F. Silas) \\ ${ }^{*}$ Corresponding author
}

\section{To cite this article:}

Clement Chiahemba Ajekwe, Adzor Ibiamke, Marie Fagson Silas. Loan Loss Provisions, Earnings Smoothing and Capital Management Under IFRS: The Case of Deposit Money Banks in Nigeria. American Journal of Management Science and Engineering.

Vol. 2, No. 4, 2017, pp. 58-64. doi: 10.11648/j.ajmse.20170204.12

Received: June 28, 2017; Accepted: July 14, 2017; Published: August 15, 2017

\begin{abstract}
The paper examines the impact of IFRS adoption on the use of loan loss provisions (LLPs) to manage earnings and capital by listed deposit money banks in Nigeria. The study employed an ex-post facto research design and a sample of fourteen (14) Deposit Money Banks listed on the Nigerian Stock Exchange. Data was obtained from 2009 to 2014 to capture the pre- and post- IFRS adoption periods. Using paired sample t-test, we find quantitative evidence to the effect that there are significant increase in the means of loan loss provisioning, and capital management by Deposit Money Banks in Nigeria in the post IFRS adoption period compared to the pre-IFRS adoption period. However, the levels of earnings smoothing are significantly lower in the post IFRS period. The implication of this finding is that adoption of IFRS improved earnings quality in the sense of reduced earnings smoothing.
\end{abstract}

Keywords: Earnings Smoothing, Capital Management, IFRS, Loan Loss Provision, Nigeria

\section{Introduction}

Loans and advances constitute the largest part of a bank's assets; being in the region of $10-15$ times larger than bank equity [1]. If serious capital depletion issues are to be avoided, provisions must be made for those loans that would be bad, non-performing or slow-moving. In Nigeria, loan loss provisioning is a major study area in accounting because of the huge losses, serious capital depletion and bank failures in the 1990s and late 2000s as a result of default of large loans given earlier by banks. Loan loss provisioning refers to deductions made from the net interest income of banks to provide for anticipated bad or non-performing loans. This practice is allowed by the applicable accounting standards and bank regulators. Extant empirical literature document evidence suggesting that loan loss provisioning (LLP) is exploited by bank managers to smooth earnings ([2], [3], [4], [5] among others) and to manage regulatory capital ([6], [1], [7], [8], [9] among others).
The Statement of Accounting Standards No. 10 (SAS 10) and the Central Bank of Nigeria $(\mathrm{CBN})$ prudential guidelines were the applicable standards for the banking industry in Nigeria up to and including December, 2011. The International Financial Reporting Standards (IFRS) were mandatorily adopted from January 1, 2012 and have since guided loan loss provisioning by Nigerian deposit money banks. Given the importance of loan loss provisions in determining reported earnings of banks and meeting other regulatory requirements [8], [10], this study expects that with the adoption of IFRS, there will be significant aggregate effects on banks' earnings quality and capital management. The expectation is that IFRS, being high quality standards, would after their mandatory adoption; reduce the ability to engage in earnings management and to manage capital to meet regulatory requirements using loan loss provisions.

This paper examines the impact of IFRS adoption on the use of loan loss provisions (LLPs) to manage earnings and regulatory capital of listed deposit money banks in Nigeria. In particular, three questions are addressed: How do loan loss 
provisions differ quantitatively before and after IFRS adoption? How significant does the level of earnings smoothing differ before and after IFRS adoption? How significant does the level of regulatory capital management differ before and after IFRS adoption? In the next section, concepts in the study are clarified along with a review of empirical literature; section 3 explains the research methods employed; section 4 presents the results; and the final section concludes the paper.

\section{Literature Review}

\subsection{Conceptual Clarifications}

This paper revolves around three main concepts: loan loss provision, earnings smoothing, and regulatory capital management. These concepts are defined and accordingly clarified.

\subsubsection{Loan Loss Provision}

Loan loss provision is a non-cash expense for banks to account for possible future losses on loan defaults. Banks assume that a certain percentage of loans will be in default or become slow-paying. Banks enter a percentage as an expense when calculating their pre-tax incomes. This guarantees a bank's solvency and capitalization if and when the defaults occur. Loan loss provision is a key accounting choice that significantly influences the earnings and capital requirements of banks. In making loans, banks face the risk that borrowers may default and the full amount of the loan will not be recovered. Rather than wait for the loss to actually occur before recognising it in the books, a bank provides for possible loan losses. Loan loss provisioning provides information to investors on the bank's assets and income which can have an effect on the bank's regulatory capital that determines the amount of Risk-Weighted Assets (RWA) that the bank must hold. The RWA is part of the capital adequacy framework that sets out the approach for the computation of minimum capital required by a banking institution to operate as a going concern. Thus, loan loss provisioning is an important subject to investors, bank regulators, standard setters and bank's management Based on the operations of a bank, an annual provisional charge to the income statement creates a loan loss reserve (shown in the bank's position statement). When the full amount of principal and interest on the loan becomes uncollectible, the loan balance is reduced through a charge to the loan loss reserve. The loan loss provision allocated each year increases with the perceived riskiness of the loans advanced to customers. Consequently, a bank making fewer risky loans will have a low loan loss provision compared to a bank making higher risky loans [11].

Before the compulsory adoption of IFRS, Nigerian banks operated under the CBN Prudential Guidelines which allowed loss provisions for specific loans identified as impaired and a general provision for loans that may be impaired. In contrast, the IFRS prescribes the incurred loss approach whereby banks provide only for losses incurred at the date of the financial position statement. Thus, general provision for loans that may be impaired, that is, losses 'expected as a result of future events' may not be recognised. The strict limitation by the standard setters to actual incurred losses has to be understood in the light of anecdotal and empirical evidence that loan loss accounting is a favoured tool for managing earnings. The summary of differences between the two regulatory frameworks is presented in Table 1.

Table 1. Banking loan loss provisioning under CBN and IFRS rules.

\begin{tabular}{|c|c|}
\hline CBN (Nigerian) guidelines & IFRS guidelines \\
\hline $\begin{array}{l}\text { Loan is impaired and loss incurred if it is probable that the bank will not be } \\
\text { able to collect all amount due, }\end{array}$ & $\begin{array}{l}\text { Loan is impaired and loss incurred if there is objective evidence of } \\
\text { impairment }\end{array}$ \\
\hline $\begin{array}{l}\text { Credit portfolio is continuously being reviewed once a quarter in order to } \\
\text { recognize deterioration in credit quality base on perceived risk of default, }\end{array}$ & $\begin{array}{l}\text { The bank shall assess at each balance sheet date whether there is any } \\
\text { objective evidence of impairment. After the initial recognition of the asset } \\
\text { and loss event has an impact on the credit quality }\end{array}$ \\
\hline $\begin{array}{l}\text { The assessment of risk default is based on criteria which include but not } \\
\text { limited to repayment performance, borrower's repayment capacity on the } \\
\text { basis of current financial condition and net realizable value of collateral }\end{array}$ & $\begin{array}{l}\text { Assessment is based on objective evidence which include significant } \\
\text { financial difficulty of the obligor, breach of contract such as a default in } \\
\text { payment of interest or principal is becoming probable that the borrower } \\
\text { will enter bankruptcy or financial reorganization and the likes }\end{array}$ \\
\hline $\begin{array}{l}\text { Credit facilities which include loans connected with banks' risk is classified } \\
\text { into performing and non performing if payment of principal and interest are } \\
\text { up to date with agreed terms or when due and not paid respectively }\end{array}$ & $\begin{array}{l}\text { Credit facilities which include loans performance is measured using fair } \\
\text { value }\end{array}$ \\
\hline $\begin{array}{l}\text { Rescheduling non-performing loan is based on borrower's capacity i.e. } \\
\text { borrower must effect cash payment such that outstanding unpaid interest } \\
\text { does not exceed } 90 \text { days }\end{array}$ & $\begin{array}{l}\text { Any outstanding unpaid which creates impairment is reduced directly or } \\
\text { through the use of allowance account and the amount of the loss recognized } \\
\text { in profit and loss }\end{array}$ \\
\hline $\begin{array}{l}\text { Provisioning on reschedule loan is continuous until it is observed for a } \\
\text { period of } 90 \text { days to be working before achange is made }\end{array}$ & $\begin{array}{l}\text { Provisioning on reschedule loan is amortized on impairment loss with } \\
\text { objective evidence }\end{array}$ \\
\hline $\begin{array}{l}\text { To reflect true financial condition, banks are to make specific and general } \\
\text { provision for perceived defaults }\end{array}$ & Only actual loss is provisioned for \\
\hline Provision is based on number of days stipulated in the guideline & Number of days is insignificant \\
\hline
\end{tabular}




\subsubsection{Earnings Smoothing}

Earnings smoothing - a form of earnings management, is generally defined as the dampening of fluctuations in reported earnings over time [12]. In smoothing earnings, management takes actions to increase earnings when earnings are relatively low and decreases earnings when earnings are relatively high. Stolowy and Bretton (2004) posit that the objective of earnings smoothing is to produce a steadily growing stream of profits for the firm; this claim could be interpreted to mean that as long as earnings are positive and increasing, it does not matter if they are more or less volatile.

Albrecht and Richardson (1990) define earnings smoothing as "the deliberate dampening of fluctuations about some level of earnings which is considered to be normal for the firm" (p. 713). This definition implies that managers try to reduce variances in reported earnings of the firm over time. However, whether smooth earnings are "a steadily growing stream of earnings" or "a deliberate dampening of fluctuations in reported earnings;" managers have incentives to smooth earnings. The capital markets appreciate companies that report highly stable earnings because it is easier for future earnings of such companies to be forecasted more accurately. Investors and analysts also perceive that smooth earnings are an indication that earnings of the reporting company will persistent in future periods [15], [16]. Similarly, firms reporting smooth earnings are considered less risky compared to firms with volatile earnings [17]. Thus, the value that the capital market places on the smoothness of earnings is a strong incentive to smoothen earnings [18]. Moreover, wider variances in reported earnings are associated with higher risk; which translates into higher capital costs. For this reasons, managers have the incentive to smooth earnings. Thus, when bank profits are abnormally high, banks tend to increase LLP to minimise the volatility of earnings. Similarly, when bank earnings are low, banks decrease LLP for the same reason- to smooth earnings.

\subsubsection{Capital Management}

In Nigeria, the prescribed minimum capital of deposit money banks is that they (a) hold a minimum regulatory capital of $\$ 25$ billion and (b) maintain a ratio of total regulatory capital to the risk-weighted asset at or above $10 \%$. The capital management hypothesis predicts that the regulatory capital ratio is negatively related to loan loss provisions because bank managers with low capital ratios increase the ratio by charging more loan loss provisions to reduce regulatory costs imposed by capital adequacy ratio regulations. Regulatory costs relate to the fact that banks with regulatory capital ratio below the minimum requirement are subject to regulatory pressure, such as being forced to merge with a stronger bank or prohibited from declaring dividends to shareholders. Therefore, banks attempting to avoid regulatory pressure and to gain public confidence have to find ways to improve their regulatory capital and financial results. One way of achieving this objective is by managing discretionary accruals via LLP [19]. Prior studies suggest that in order to achieve capital adequacy ratios and avoid violating minimum capital requirements, banks increase loan loss provisions when regulatory capital is low and decrease loan loss provision when regulatory capital is high [1], [8], [9], [20].

\subsection{Empirical Literature}

Evidence of whether banks use LLP to smooth earnings is mixed. Kanagaretnam, Lobo and Yang (2004) examine whether and how bank managers use loan loss provisions to smooth earnings and to signal their private information about their banks' future prospects. The authors found evidence consistent with the use of loan loss provisions to smooth earnings, particularly when pre-managed earnings are extreme.

Greenawalt and Sinkey (1988) studied bank loan loss provisions and the earnings smoothing hypothesis by focusing on the function of loan loss provisions in managing capital and earnings; they found evidence that bank managers use their discretion to manipulate earnings. Wall and Koch (2000) after a review of theoretical and empirical evidence on earnings management via loan loss accounting in the US summarised evidence, confirming earlier study by [7] that banks both have an incentive to and generally use loan loss accounting to manage reported earnings. On the other hand, some studies hardly found evidence of earnings smoothing via LLP after Basel 1 [8], [22].

Perez, Salas-Fumá s and Saurina (2008) tested earnings smoothing and capital management practices through loan loss provisions by Spanish banks. Using panel data econometric techniques, they found evidence of earnings smoothing through LLP but not of capital management. Using a sample of 878 US bank holding companies over the period 2001-2009, [4] found strong evidence of earnings smoothing behaviour. Additionally, bank holding companies accelerate loan loss provisions to smooth earnings when banks: hit the regulatory minimum target, are in non-recessionary periods, and are more profitable. The author also found that banks use loan loss provisions more extensively during the crisis period to smooth income upward.

Given a sample of 15,268 US banks over the period 19962011, [5] main results suggest that, depending on the size of earnings, bank managers tend to engage in earnings-decreasing strategies when earnings are negative ("big-bath"), use earnings-increasing strategies when earnings are positive, and use provisions as a smoothing device when earnings are positive and substantial ("cookie-jar" accounting).

Gebhardt and Novotny - Farkas (2011) looked at loan loss provisions for banks in 12 European countries. They concluded that the tighter loan loss provisioning rules in the IFRS (IAS 39) significantly reduced discretionary behaviour compared to before, as measured by less earnings smoothing. However, they also found that banks delayed recognition of loan losses and then recognised accumulated losses over more than one period, distorting the flow of earnings. The authors observed that this effect is likely to be more 
pronounced during economic downturns. Onalo, Mohd, and Ahmad (2014) also discovered that Nigerian and Malaysian banks use LLP to manage reported earnings before the adoption of IFRS; but noticed lower earnings management via LLP in the post IFRS adoption period.

On whether LLP will be used to manage earnings and capital after IFRS adoption, [25] reported that earnings management using loan loss provisions was significant over the entire study period. However, it was lower after IFRS adoption in 2005. The authors concluded that implementation of IFRS in the EU improved the banks' earnings quality by mitigating the tendency of managers of listed commercial banks to engage in earnings management using loan loss provisions. Following the empirical iterature above, this paper hypothesises as follow:

$\mathrm{H} 1$ a: There is a significant difference in loan loss provision before and after IFRS adoption by listed deposit money banks in Nigeria

$\mathrm{H} 1 \mathrm{~b}$ : There is a significant difference in earnings smoothing before and after IFRS adoption by listed deposit money banks in Nigeria

Moyer (1990) presents evidence that the capital adequacy ratio is significantly negatively related to loan loss provisions, implying that bank managers adjust loan loss provisions to reduce regulatory costs. By the same token, [26] proposed that the reason for earnings manipulation in banks is to maintain a desirable regulatory capital requirements ratio thus avoiding unnecessary regulatory costs. The author argued that banks do not wait until they are below the regulatory standard before they begin managing capital as suggested by the regulatory capital management hypothesis; rather capital is managed in anticipation of failure to meet the minimum regulatory capital threshold.

Anandarajan, Hassan and McCarthy (2007) examine whether and to what extent Australian banks use loan loss provisions (LLPs) for capital and earnings management. They examined if there were changes in the use of LLPs as a result of the implementation of banking regulations consistent with the Basel Accord of 1988, which made loan loss reserves no longer part of Tier I capital in the numerator of the capital adequacy ratio. They find some evidence to indicate that Australian banks use LLPs for capital management, but find no evidence of a change in this behaviour after the implementation of the Basel Accord. Their results indicate that banks in Australia use LLPs to manage earnings. Furthermore, listed commercial banks engage more aggressively in earnings management using LLPs than unlisted commercial banks. They also find that earnings management behaviour is more pronounced in the post-Basel period. Overall, their study shows evidence of a significant understating of LLPs in the post-Basel period relative to the pre-Basel period. This indicates that reported earnings might not reflect the true economic reality underlying those numbers.

Ahmed, Takeda and Thomas (1999) studied the 1990 change in capital adequacy regulations in the USA to construct more powerful tests of capital and earnings management effects on bank loan loss provisions and found strong support for the hypothesis that loan loss provisions are used for capital management. However, as indicated earlier, they did not find evidence of earnings management via loan loss provisions.

Scholes, Wilson and Wolfson (1990) examined the use of LLP and other tools for capital management and found that banks used LLPs to manage capital ratios by inflating loan loss reserves when the capital amounts were close to violating minimum requirements. They found no significant associations with other tools so they concluded that LLP was used to manage capital. The study by [28] on loan loss provision decisions of Spanish banks found that loan loss provisioning was used to manage earnings and capital. Concerns about the improper use of loan loss provisioning prompted the International Accounting Standards Board (IASB) to replace existing "incurred loss methods" with IFRS 9, a "forwardlooking expected loss method" in July 2014. This study does not include research on this new requirement/standard. Accordingly also this study hypothesises that:

$\mathrm{H}$ 2: There is a significant difference in regulatory capital before and after IFRS adoption by listed deposit money banks in Nigeria

\section{Methodology}

This study employed an ex-post facto research design. The population of the study consisted of all the twenty one (21) deposit money banks listed on the Nigerian Stock Exchange as at December, 31st 2014. As a result of the difficulty involved in obtaining comparable data from 2009 to 2014 to capture the preand post- IFRS adoption periods, and also because of changes in some banks due to mergers and outright acquisitions, this study applied a filter to exclude banks that are unsuitable for collecting data for this study. A usable sample size of fourteen (14) banks was used for the six-year period; three years (2012-2014) post IFRS adoption period and three years pre IFRS adoption period (2009-2011). Relevant data are collected and extracted from the published annual financial reports and accounts of the fourteen (14) sampled banks.

\subsection{Measurements of Variables Employed in the Study}

(1) Loan loss provision is a non-cash expense for banks to account for possible future losses on loan defaults. Banks assume that a certain percentage of loans will be in default or become slow-paying. Banks enter a percentage as an expense when calculating their pre-tax incomes. This guarantees a bank's solvency and capitalization if and when the defaults occur. The loan loss provision allocated each year increases with the riskiness of the bank's loan portfolio. A bank with a small number of risky loans will have a low level of loan loss provision compared to a bank taking higher risks. Allowance for loan losses is calculated as the sum of any specific, generic and other types of allowances for loan losses, which might also include those that have been temporarily created in addition to 
generic and specific provisions. Loan loss provisions are calculated by adding provisions for credit losses, releases of provisions and recoveries, direct write-off of loans and advances and other loan loss provisions. These were extracted from the published financial statements of the sampled banks.

(2) Earnings smoothing was measured by the ratio of the standard deviation of net income $(\sigma \mathrm{NI})$ to the standard deviation of cash flows from operations $(\sigma \mathrm{CF})$, [i.e., $\sigma N I / \sigma C F]$. This measure is one of three measures commonly used in the literature [29], [30], [31]. Low values of this measure indicate that, all things being equal, earnings have been smoothened. That is, a lower variation in earnings relative to variation in cash flows is evidence of earnings smoothing [32]; hence a lower value of this metric signifies a smoother earnings stream.

(3) Regulatory capital is the amount of capital required by regulation. For example, the $\mathrm{CBN}$ requires banks to maintain a regulatory capital at $\$ 25$ billion and a ratio of total regulatory capital to the risk-weighted asset at or above $10 \%$. Banks have incentives to manage capital because of the close monitoring by the $\mathrm{CBN}$, which measures deposit money banks' performance in terms of capital adequacy. Without regulatory capital requirement, companies may not have any incentive to keep a large amount of capital; companies may have alternative use for their funds to engage in business initiative (s) with a view to making profits. Also, raising capital dilutes the return for existing shareholders and senior management of companies who have share options. This can create disincentive for senior management to raise capital. The regulatory capital is determined from the financial statements of the sampled banks.

\subsection{Comparative Analysis}

The paired sample t-test was used to compare and test whether the differences in the loan loss provisions, earnings smoothing and capital management in the pre and post IFRS adoption periods are significant. The paired sampled t-test is calculated as follows:

$$
t=\frac{\bar{d}}{s_{d} \sqrt{n}}
$$

where

$\bar{d}=$ mean of the difference between the paired groups of the variables before and after adoption of IFRS.

$s_{d}=$ the standard deviation of the variables (loan loss provision, earnings smoothing and regulatory capital) of the banks under CBN prudential guidelines and under IFRS.

$\mathrm{N}=$ the total number of number of banks studied (14 in all).

\section{Results and Discussions}

Table 2 displays the descriptive statistics of the study variables. For each loan loss provisioning frameworks, the table depicts the minimum, maximum, mean, standard deviation, skewness and kurtosis. In this paper, all the variables have skewness values of less than \pm 1.0 suggesting that the distributions are approximately normal.

Table 2. Descriptive Statistics.

\begin{tabular}{|c|c|c|c|c|c|c|c|c|c|}
\hline & \multirow[t]{2}{*}{$\mathbf{N}$} & \multirow[t]{2}{*}{ Min } & \multirow[t]{2}{*}{ Max } & \multirow[t]{2}{*}{ Mean } & \multirow[t]{2}{*}{ Std Dev } & \multicolumn{2}{|c|}{ Skewness } & \multicolumn{2}{|c|}{ Kurtosis } \\
\hline & & & & & & Stats & Std error & Stats & Std error \\
\hline LLP- IFRS & 14 & 3.454 & 6.359 & 4.960 & 0.790 & -0.155 & 0.597 & -0.306 & 1.154 \\
\hline LLP-CBN & 14 & 3.077 & 4.977 & 3.957 & 0.598 & 0.384 & 0.597 & -0.908 & 1.154 \\
\hline SMOOTH-IFRS & 14 & 1.910 & 3.657 & 2.569 & 0.618 & 0.405 & 0.597 & -1.256 & 1.154 \\
\hline SMOOTH- CBN & 14 & 1.164 & 1.953 & 1.636 & 0.267 & -0.477 & 0.597 & -0.858 & 1.154 \\
\hline CAPITAL-IFRS & 14 & 2.069 & 2.981 & 2.467 & 0.295 & 0.534 & 0.597 & -1.159 & 1.154 \\
\hline CAPITAL- CBN & 14 & 1.408 & 2.570 & 1.951 & 0.381 & 0.527 & 0.597 & -0.647 & 1.154 \\
\hline
\end{tabular}

Source: SPSS Version 16 Output

Table 3 depicts the differences between the means of the loan loss provisions, earnings smoothing and regulatory capital under the two banking regulatory frameworks. According to Table 3, the differences between the mean values of each pair of scores (i.e., $\bar{d}$ in Equation 1) are: 1.003(4.960-3.957) for Pair 1 (loan loss provision under IFRS and CBN frameworks); 0.933(2.569-1.636) for Pair 2 (earnings smoothing before and after IFRS adoption) and 0.516(2.467-1.951) for Pair 3 (regulatory capital after and before IFRS adoption).

Table 3. Paired Samples Test.

\begin{tabular}{|c|c|c|c|c|c|c|c|c|}
\hline & \multicolumn{5}{|c|}{ Paired Differences } & \multirow{3}{*}{$\mathbf{t}$} & \multirow{3}{*}{ df } & \multirow{3}{*}{ Sig. (2-tailed) } \\
\hline & \multirow{2}{*}{ Mean } & \multirow{2}{*}{$\begin{array}{l}\text { Std. } \\
\text { Deviation }\end{array}$} & \multirow{2}{*}{$\begin{array}{l}\text { Std. Error } \\
\text { Mean }\end{array}$} & \multicolumn{2}{|c|}{ 95\% Confidence Interval of the Difference } & & & \\
\hline & & & & Lower & Upper & & & \\
\hline $\begin{array}{l}\text { Loan Loss ProvisionUnder IFRS - } \\
\text { LoanLoss Provision underCBN }\end{array}$ & 1.003 & 0.808 & 0.216 & 0.537 & 1.469 & 4.648 & 13 & .000 \\
\hline $\begin{array}{l}\text { Earnings Smoothing Under IFRS - } \\
\text { Earnings Smoothing Under CBN }\end{array}$ & 0.933 & 0.713 & 0.191 & 0.522 & 1.346 & 4.899 & 13 & .000 \\
\hline $\begin{array}{l}\text { Regulatory Capital under IFRS - } \\
\text { Regulatory Capital under CBN }\end{array}$ & 0.516 & 0.462 & 0.124 & 0.250 & 0.783 & 4.182 & 13 & .001 \\
\hline
\end{tabular}


The fact that the t-values are positive means that the first condition (loan loss provision under IFRS, earnings smoothing under IFRS and regulatory capital under IFRS) had larger mean values than the second condition (loan loss provision under CBN guidelines, earnings smoothing under CBN guidelines and regulatory capital under CBN guidelines). Therefore, the conclusion is that loan loss provisions, earnings smoothing and capital management under IFRS are significantly higher than those under the CBN prudential guidelines [i.e., (in pair 1: $\mathrm{t}(13)=4.648$, $\mathrm{p}$ $=0.000)$; (in pair $2: \mathrm{t}(13)=4.899, \mathrm{p}=0.000) ;($ in pair $3: \mathrm{t}(13)$ $=4.182, \mathrm{p}=0.001)]$.

\section{Conclusions}

This paper finds evidence to the effect that there are significant increases in the means of loan loss provisioning, and capital management by deposit money banks in Nigeria in the post IFRS adoption period compared to the pre-IFRS adoption period. However, the levels of earnings smoothing are significantly lower in the post IFRS period. The implication of this finding is that adoption of IFRS improved earnings quality in the sense of reduced earnings smoothing (standard deviation of earnings relative to standard deviation of cash flows in the post IFRS period (0.618) is higher than in the pre-adoption period $(0.267))$. However, the increased LLPs by deposit money banks in Nigeria in the post IFRS adoption period may have been used to manage capital to achieve regulatory adequacy requirements.

These results are largely expected: CBN prudential guidelines were rule-based without any managerial discretion in estimating loan loss provisions and consequently, capital management. In contrast, IFRS, being principles-based, provide management with some flexibility in estimating loan loss provisions. The use of management judgment should result to high earnings quality (lower earnings smoothing) even in the context of higher loan provisions.

\section{References}

[1] Wahlen J. M. (1994). The nature of information in commercial bank loan loss disclosures. The Accounting Review, 69, 455478 .

[2] Kanagaretnam, K., Lobo, G. J. \& Yang, D. H. (2004). Joint tests of signalling and income smoothing through bank loan loss provisions. Contemporary Accounting Research, 21(4), 843-884.

[3] Pérez, D., Salas-Fumás, V. \& Saurina, J. (2008). Earnings and capital management in alternative loan loss provision regulatory regimes. European Accounting Review, 17, 423-445.

[4] El-Sood, H. A. (2012). Loan loss provisions and income smoothing in US banks pre and post the financial crisis. International Review of Financial Analysis, 25, 64-72.

[5] Balboa, M., López-Espinosa, G. \& Rubia, A. (2013). Nonlinear dynamics in discretionary accruals: An analysis of bank loan-loss provisions. Journal of Banking \& Finance, 37(12), 5186-5207.

[6] Moyer. S. E. (1990). Capital adequacy ratio regulations and accounting choices in commercial banks. Journal of Accounting and Economics, 13(2), 123-154.

[7] Beatty. A., Chamberlain, S. L. \& Magliolo, J. (1995). Managing financial reports of commercial banks: The Influence of taxes, regulatory capital and earnings. Journal of Accounting Research, 33(2), 231-262.

[8] Ahmed, A. S., Takeda, C. \& Thomas, S. (1999). Bank loan loss provisions: A re-examination of capital management, earnings management and signalling effects. Journal of Accounting and Economics, 28, 1-25.

[9] Wall, L. D. \& Koch, T. W. (2000). Bank loan-loss accounting: A review of theoretical and empirical evidence. Economic Review, (2), 1-20.

[10] Nichols, D., Wahlen, J. \& Wieland, M. (2009). Publicly-traded versus privately-held: implications for bank profitability, growth risk, and accounting conservatism. Review of Accounting Studies, 14, 88-122.

[11] Angklomkliew, S., George, J. \& Packer, F. (2009). Issues and developments in loan loss provisioning: The case of Asia. BIS Quarterly Review, December, 69 - 83.

[12] Ronen, J. \& Yaari, V. (2008). Earnings management: Emerging insights in theory, practice, and research. New York: Springer.

[13] Stolowy, H. \& Bretton, G. (2004). Accounts manipulation: A literature review and proposed conceptual framework. Review of Accounting and Finance, 3(1), 5-66.

[14] Albrecht, W. D. \& Richardson, F. M. (1990). Income smoothing by economic sector. Journal of Business Finance and Accounting, 17, 713-730.

[15] Jiang, G., Lee, C. \& Zhang, Y. (2005). Information uncertainty and expected returns. Review of Accounting Studies, 10 (2-3), $185-221$.

[16] Tucker, X. J. \& Zarowin, P. (2006). Does income smoothing improve earnings informativeness? The Accounting Review, 81(1), 251-270.

[17] Wang, Z. \& Williams, T. H. (1994). Accounting income smoothing and stockholder wealth. Journal of Applied Business Research, 10(3), 96-104.

[18] Graham, J. R., Harvey, C. R. \& Rajgopal, S. (2005). The economic implications of corporate financial reporting. Journal of Accounting and Economics, 40(1-3), 3 - 73.

[19] Shaharudin, R. S. (2004) A review on accounts manipulation via loan loss provisions to manage regulatory capital and earnings along business cycle. Juma Ekonomi Malaysia, 38, $99 \cdot 123$.

[20] Anandarajan, A., Hasan, I. \& McCarthy, C. (2007). Use of loan loss provisions for capital, earnings management and signalling by Australian banks. Accounting and Finance, 47(3), 357-79.

[21] Greenawalt, M. B. \& Sinkey, Jr, J. F. (1988). Bank loan-loss provisions and the income-smoothing hypothesis: An empirical analysis 1976-1984. Journal of Financial Services Research, 1(4), 301-318. 
[22] Wetmore, J. L. \& Brick, J. R. (1994). Loan loss provisions of commercial banks and adequate disclosure: A note. Journal of Economics and Business, 46, 299-305.

[23] Gebhardt, G. \& Novotny-Farkas, Z. (2011). Mandatory IFRS adoption and accounting quality of European banks. Journal of Business Finance and Accounting, 38 (3/4), 289-333.

[24] Onalo, U., Mohd, L. \& Ahmad, K. (2014). The effects of changes in accounting standards on earnings management of Malaysia and Nigeria banks. European Journal of Accounting Auditing and Finance Research, 2(8), 15-42.

[25] Leventis, S., Dimitropoulos, P. E. \& Anandarajan, A. J (2011). Loan loss provisions, earnings management and capital management under IFRS: The case of EU commercial banks. Journal of Financial services research, 40, 103-122. doi: 10.1007/s 10693-010-0096-1.

[26] Bernard. V. L. \& Skinner, D. J. (1996). What motivates manager's choice of discretionary accruals? Journal of Accounting and Economics, 22, 313-325.

[27] Scholes, M., Wilson, G. P. \& Wolfson, M. (1990). Tax planning, regulatory capital planning and financial reporting strategy for commercial banks. Review of Financial Studies, 3, 625-650.
[28] Anandarajan, A., Hasan, I. \& Lozano-vivas, A. (2003). The role of loan loss provisions in earnings management, capital management, and signalling: The Spanish experience. Advances in International Accounting, 16, 43-63.

[29] Leuz, C. Nanda, D. \& Wysocki, P. (2003). Earnings management and investor protection: An international comparison. Journal of Financial Economics, 69, 505-527.

[30] Myers, J. N., Myers, L. A. \& Skinner, D. J. (2006): Earnings momentum and earnings management. Accessed on 11 May 2017 at SSRN: https://ssrn.com/abstract $=741244$ or http://dx.doi.org/10.2139/ssrn.741244

[31] Land, J. \& Lang, M. H. (2002). Empirical evidence on the evolution of international earnings. The Accounting Review, 77(s-1), 115-133.

[32] Zarowin, P. (2002). Does income smoothing make stock prices more informative? NYU Working Paper. Accessed on 8 May 2017 at SSRN: https://ssrn.com/abstract $=1281356$ 